\title{
福島前面海域における放射性污染水の濃度解析 CONCENTRATION ANALISIS OF RADIOACTIVE CONTAMINATION WATER IN THE PACIFIC IN FRONT OF FUKUSHIMA
}

\author{
中村 倫明 1 落合 実 2 鷲見 浩一 3 ・和田 明 4 \\ Tomoaki NAKAMURA, Minoru OCHIAI, Hirokazu Sumi and Akira WADA \\ 1正会員 博 (工) 日本大学助手 生産工学部土木工学科（†275-8575 千葉県習志野市泉町1-2-1） \\ 2正会員 博（工）日本大学教授 生産工学部土木工学科（†275-8575 千葉県習志野市泉町1-2-1） \\ 3 正会員 博 (工) 日本大学准教授 生産工学部土木工学科（二275-8575 千葉県習志野市泉町1-2-1） \\ 4正会員 工博 日本大学名誉教授 大学院総合科学研究科（干102-0076 東京都千代田区五番町12-5）
}

\begin{abstract}
Object of this study is to predict distribution of radioactive contamination water in front of Fukushima by means of a 3-dimensional flow model linked with a diffusion model, released by Fukushima Daiichi Nuclear Power Plant. It was confirmed that radionuclides(Cs-137,Sr-90,H-3) distributions in coastal areas can be predicted by means of nesting form the whole Pacific Ocean model. Results were compared to the published observation data in order to examine applicability of the used models.
\end{abstract}

As a result, the impossibility of the influence humanities was suggested to be with in front of Fukushima.

Key Words : Fukushima Daiichi Power Plant, Concentration Analysis, Numerical Model

\section{1.はじめに}

平成23年3月に発生した東日本大震災に伴い，東京電 力株福島第一原子力発電所（以下，福島第一原発）加 放出される放射性物質が環境へ与える影響について, 3 年経った現在でも十分な影響評価がなされておらず，避 難住民や帰宅する住民に不安が広がっている．特に，海 洋一放出された放射性物質は, 海洋生物や海底生物に蓄 積され，やがて人へも影響が及よぶことから，地場産業 でもある漁業への影響が懸念されている. そこで，海洋 環境中のモニタリングとして, 平成24年 3 月 30 日から文 部科学省・水産庁・国土交通省・海上保安庁・気象庁・ 環境省・福島県・東京電力株式会社を中心に「福島沖海 水及び海底土の平成24年度海域モニタリング調査方針

(改定版) 」に従って，海水及び海底土のサンプリング が行われている. しかしながら, 福島第一原発の前面海 域は, 太平洋に面しており広大な場所での調査となるこ とから，3次元的な拡散状況の把握や，より広域におけ る濃度状況の把握や今後の中・長期的な予測については 困難な状況にある.

海域中の放射性物質は，溶存態物質と懸濁態物質に大 別され溶存態物質は移流・拡散効果により希勫しながら
広がっていく、䀣濁態物質は移流しながら，吸着した粒 子と共に下層へと沈降する. 海域における物質の拡散計 算はこれまでに多く実施されてきた。しかしながら，放 射性物質は核種の種類によっても移行に違いが生じるこ とがあることなどから，多くの知見は存在していない． 東日本大震災後の放射性物質の拡散予測について, 津旨 ${ }^{1}$ は沿岸海洋モデル(ROMS)を利用し福島沖を中心とした 日本近海の解析を，松浦 ${ }^{2}$ はHybrid box modelによる福島 沖の解析を, Honda et al. ${ }^{3)}$ は全球モデルによる解析を実 施している。これらは, 海底への沈降または海底下の放 射性物質の移行過程を十分に考慮していないため, 短期 間における再現を行ったに留まり，長期にわたる予測を 行っていないほか, 環境アセスメントとして評価を行っ ているものではない.

本研究では，2011年の福島第一原発における一時期的 な海洋への放射性物質の漏洩ではく, 継続的, かつ中長 期的に評価を要する污染水に対し, 海水に放出された放 射性物質が懸濁粒子に吸着し沈降寸る過程（スキャベン ジング4) を考慮した数理モデルを展開し，5年後の放 射性物質拡散状況の把握及び国際放射線防護委員会 (ICRP)の評価手法による人への影響評価を行うことを目 的とする. 


\section{2. 太平洋における数理モデルの概要}

\section{（1）流動モデル概要及び結果}

本研究は概要である福島沖に対し, 福島第一原発から 恒常的に発生する污染水を中・長期的に海洋一拡散させ ることに対する将来予測（環境影響評価）することを目 的としており，考慮すべき流動場の時間・空間スケール は平均流モデルによる結果で良いと考えられる。

そこで本計算に用いたモデルはWada et al..$^{5} や$, Hasegawa et al. ()によって数十年における放射性物質を卜 レーサーとした再現性を十分に行っている太平洋全域の 平均流モデルをもとに, 福島前面海域の計算格子を著者 らのが用いたネスティング手法により $2 \mathrm{~km} \times 2 \mathrm{~km}$ に詳細化 し流動計算の適応が可能であるとした.

計算対象範囲は太平洋全域 $\left(110^{\circ} \mathrm{E} \sim 70^{\circ} \mathrm{W}, 60^{\circ} \mathrm{N} \sim\right.$ $74^{\circ} \mathrm{S}, \mathrm{C}$-grid) とし水平解像度を $2^{\circ} \times 2^{\circ}$, 鉛直方向の計算 メッシュは第1層：0～20m，第2層：20～50m，第3層： $50 \sim 100 \mathrm{~m}$ ，第4層：100２00m，第5層 : 200 400m，第 6層： 400 600m，第7層： $600 \sim 800 \mathrm{~m} ，$ 第8層 : 800 $1000 \mathrm{~m}$, 第9層: $1000 \sim 1250 \mathrm{~m}$, 第10層 : $1250 \sim 1500 \mathrm{~m}$, 第 11 層：1500 1750m，第12層：1750～2000m，第 13 層：2000 2500m，第14層：2500～3500m，第15層： 3500 4500m，第16層: 4500〜5500mの可変メッシュ区 切りとした。沿岸域では $\mathrm{N} 34.0^{\circ} \sim \mathrm{N} 40.0^{\circ}, \mathrm{E} 140.0^{\circ} \sim$ $\mathrm{E} 148.0^{\circ}$ の範囲の水平解像度を $0.2^{\circ} \times 0.2^{\circ}$ とし, さらに $\mathrm{N} 36.6^{\circ} \sim \mathrm{N} 38.2^{\circ}, \mathrm{E} 140.6^{\circ} \sim \mathrm{E} 142.6^{\circ}$ の範囲を $0.02^{\circ} \times 0.02^{\circ}$ に 細分化した.

図-1に福島前面海域 (水平解像度 $0.02^{\circ}$ ) における水平 及び鉛直の流速べクトル図を示寸．海岸近くでは地形に 沿った流れとなり, 流速が小さい傾向になった. また,

この海域では黒潮の影響を受け東側に向く流れが強いこ とが分かる.この流れを用いて放射性物質の拡散解析を 行い，再現性については拡散解析結果によって最終的な 判断を行うこととする.

\section{（2）拡散計算の概要}

放射性物質は海洋中の移流拡散のほかに，希勫過程に おいて核種毎に特有の崩壊が生ずるとともに，核種が海 洋中の懸濁物質に吸着し沈殿除去される現象（スキャベ ンジング4)）の影響を受ける。これらを考慮した海洋中 の放射性核種濃度拡散解析の基礎式を次式で表す。太平 洋全域に対し座標系は球面座標 $(\lambda, \varphi, r)$ を採用し, $\lambda$ は緯度, $\varphi$ は経度, $\mathrm{r}$ は鉛直上向き正とする.

$$
\frac{\partial C}{\partial t}+L(C)=R\left(A_{h}, A_{v}, C\right)-D\left(\lambda_{n}, C\right)-S\left(K_{d}, \rho_{s}, w_{s}, C\right)
$$

\section{- 移流項}

$L(C)=\frac{1}{r \cos \phi}\left\{\frac{\partial}{\partial \lambda}(u C)+\frac{\partial}{\partial \phi}(v \cos \phi C)\right\}+\frac{1}{r^{2}} \frac{\partial\left(w r^{2} C\right)}{\partial r}$
- 拡散項

$$
\begin{aligned}
R\left(A_{h}, A_{v}, C\right)=A_{h} & \cdot \frac{1}{r \cos \phi}\left\{\frac{1}{r \cos \phi} \frac{\partial^{2} C}{\partial \lambda^{2}}+\frac{1}{r} \frac{\partial}{\partial \phi}\left(\cos \phi \frac{\partial C}{\partial \phi}\right)\right\} \\
& +A_{v} \cdot \frac{1}{r^{2}} \frac{\partial}{\partial r}\left(r^{2} \frac{\partial C}{\partial r}\right)
\end{aligned}
$$

- 崩壊項

$D\left(\lambda_{n}, C\right)=\lambda_{n} \cdot C$

・スキャベンジング項

$S\left(K_{d}, \rho_{s}, w_{s}, C\right)=K_{d} \cdot \rho_{s}(r) \cdot w_{s} \cdot \frac{1}{r^{2}} \frac{\partial\left(r^{2} C\right)}{\partial r}$

ここで，C: 放射性核種濃度 $\left(\mathrm{Bq} / \mathrm{m}^{3}\right), t$ : 時間 $(\mathrm{s})$, $A_{h}$ : 水平拡散係数 $\left(\mathrm{m}^{2} / \mathrm{s}\right), A_{v}$ : 鉛直拡散係数 $\left(\mathrm{m}^{2} / \mathrm{s}\right)$, $\lambda_{n}$ : 放射性核種の崩壊定数 $(1 / \mathrm{s}), K_{d}$ : 放射性核種の分 配係数 $\left(\mathrm{m}^{3} / \mathrm{g}\right), \rho_{s}$ : 海洋中の懸濁物質の濃度 $\left(\mathrm{g} / \mathrm{m}^{3}\right)$, $w_{s}:$ 懸濁物質の沈降速度 $(\mathrm{m} / \mathrm{s})$ である.

計算に用いた諸条件については表-1のとおりである. ここでは，海水中の放射性物質におけるパラメータの検 討が行われた水落( お)よび津旨9), 10)で用いられた值を参考 とした. また負荷量として, 原子力安全・保安院が 6 月 6 日に発表した放射性物質の放出量情報等をもとに 独立行政法人日本原子力研究開発機構 ${ }^{11}$ が推定した $8.45 \mathrm{PBq} （=15 \mathrm{PBq} \times 0.5$ （大気を経由） $+(0.94+$ 0.0096） $\mathrm{PBq}$ (海洋一直接））を, 福島第一原子力発電 所全面海域に全量を投入し，それ以降の放出はないもの

\begin{tabular}{|c|c|c|}
\hline \multicolumn{2}{|l|}{ 項目 } & 設定値 \\
\hline \multicolumn{2}{|c|}{ 入力した流速 } & $\begin{array}{l}\text { 北太平洋における } \\
\text { 3次元流動結果 }\end{array}$ \\
\hline \multirow{3}{*}{\multicolumn{2}{|c|}{ メッシュ }} & BLOCK1 $2^{\circ} \times 2^{\circ}$ \\
\hline & & $\begin{array}{ll}\text { BLOCK2 } & 0.2^{\circ} \times 0.2^{\circ}\end{array}$ \\
\hline & & BLOCK3 $0.02^{\circ} \times 0.02^{\circ}$ \\
\hline \multirow{2}{*}{ 拡散係数 } & 水平方向渦動拡散係数 & $1.0 \times 10^{3}\left[\mathrm{~m}^{2} / \mathrm{s}\right]^{8)}$ \\
\hline & 鉛直方向渦動拡散係数 & $1.0 \times 10^{-4}\left[\mathrm{~m}^{2} / \mathrm{s}\right]^{8)}$ \\
\hline \multicolumn{2}{|c|}{ 懸濁物質の濃度 } & $\begin{array}{l}\text { 表 層濃 度 : } \rho \mathrm{s}(0)=0.25 \\
\left(\mathrm{~g} / \mathrm{m}^{3}\right)^{9,10)} \\
\text { 深さd }(\mathrm{m}) \text { 方向の分布: } \\
\rho \mathrm{s}(\mathrm{d})=\rho \mathrm{s}(0) \times 10^{-0.0005 \mathrm{~d} 9,10)}\end{array}$ \\
\hline 沈降速度 & $\begin{array}{l}\text { 大粒子 } \\
(50 \mu \mathrm{m} \text { 以上, } 4 \%) \\
\mathrm{W} 1=100(\mathrm{~m} / \mathrm{day}) \\
\text { 小粒子 } \\
(50 \mu \mathrm{m} \text { 以下, } 96 \%) \\
\mathrm{W} 2=100(\mathrm{~m} / \mathrm{year})\end{array}$ & $\mathrm{Ws}=4.93 \times 10^{-5}(\mathrm{~m} / \mathrm{s})^{9), 10)}$ \\
\hline \multirow{3}{*}{ 負荷量 } & 核種 & $137 \mathrm{Cs}$ \\
\hline & 放出地点 & $\begin{array}{l}\text { 東京電力(株)福島第一原 } \\
\text { 子力発電所全面海域 }\end{array}$ \\
\hline & 放出量 & $8.45 \times 10^{15}$ \\
\hline \multicolumn{2}{|c|}{ 放射性物質の半滅期 } & 30 年 \\
\hline \multicolumn{2}{|c|}{ 放射性物質の分配係数 } & $2.0 \times 10^{-3} \mathrm{~m}^{3} / \mathrm{g}$ \\
\hline \multicolumn{2}{|c|}{ 海表面からのフォールアウ卜 } & 考慮しない \\
\hline \multirow{2}{*}{ 計算制御 } & 時間刻夕 & $600[\mathrm{~s}]$ \\
\hline & 反復回数 & 367920 （7年間分） \\
\hline
\end{tabular}
とした.

\section{表-1 拡散計算の諸条件}




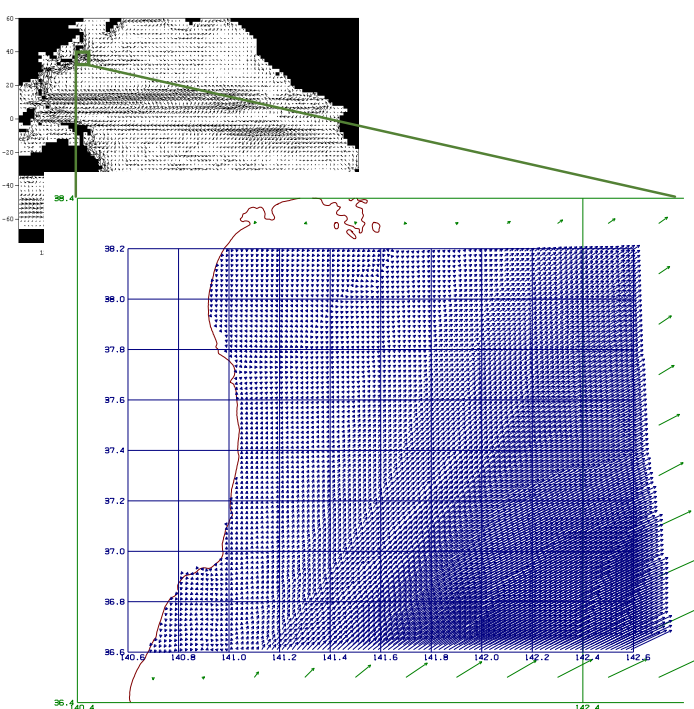

図-1＼cjkstart福島前面海域の流速ベクトル(表層)

\section{(3) 解析結果及び検証}

まず，流動計算結果，放射性物質の拡散計算結果の妥 当性を検証するため，2011年4月に海域一放出された放 射性物質を対象とし，太平洋全域の濃度計算を行った。 太平洋全域における放射性物質の観測值は少ないことか ら，既にコンセンサスを得ている原子力開発研究機構 (LAMER) ${ }^{10)}$ による計算結果との比較によって本計算結 果の検証を行った．LAMERの流速場のメッシュは水平 2 度（約 $200 \mathrm{~km} \times 200 \mathrm{~km}$ ) , 鉛直15層である. 図2, 図3 に本計算結果及びLAMERによる 1 年後，7年後における $137 \mathrm{Cs}$ 濃度計算結果を示す.

図2，図3における ${ }^{137} \mathrm{Cs} の$ 分布は，概ね整合がとれてい る. また, 本計算結果での1年後の最大濃度は $0.082 \mathrm{~Bq} / \mathrm{L}$ に対し, 原子力開発研究機構では $0.023 \mathrm{~Bq} / \mathrm{L}$ とオーダー は同レベルとなっている。一方で，太平洋全域において， 本計算結果の方が東側への広がりが小さくなっている.

この理由としてLAMERでは放射性物質の沈降過程は考 慮されておらず，表層濃度は課題評価されている可能性 がある．また，LAMERによる結果では実測值との比較 は行っていないが，本計算に結果に対する実測值との比 較として，以下に説明するとおり外洋域での相関は 0.89 と高いものとなっている.

次に，実測值と計算值の関係性をみるため，東京電力

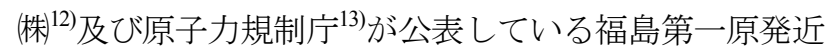
傍域，原子力規制庁 ${ }^{14}{ }^{13}$ が公表している福島第一原発周辺 海域(20km圈内), 海上保安庁 ${ }^{15}$ が公表している福島沖,

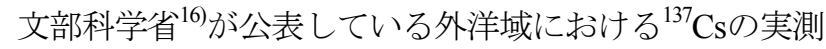
值と計算值の相関関係を図-4に示す．これによれば，福 島第一原発周辺海域，外洋域は相関関係が高い $(\mathrm{R}=0.7$, 0.89). 一方で福島沖及び福島第一原発周辺海域の 2 年後, 3年後については，計算值が小さく相関関係は低い，放 射性物質の負荷は，海洋一の直接的な負荷以外に，大気
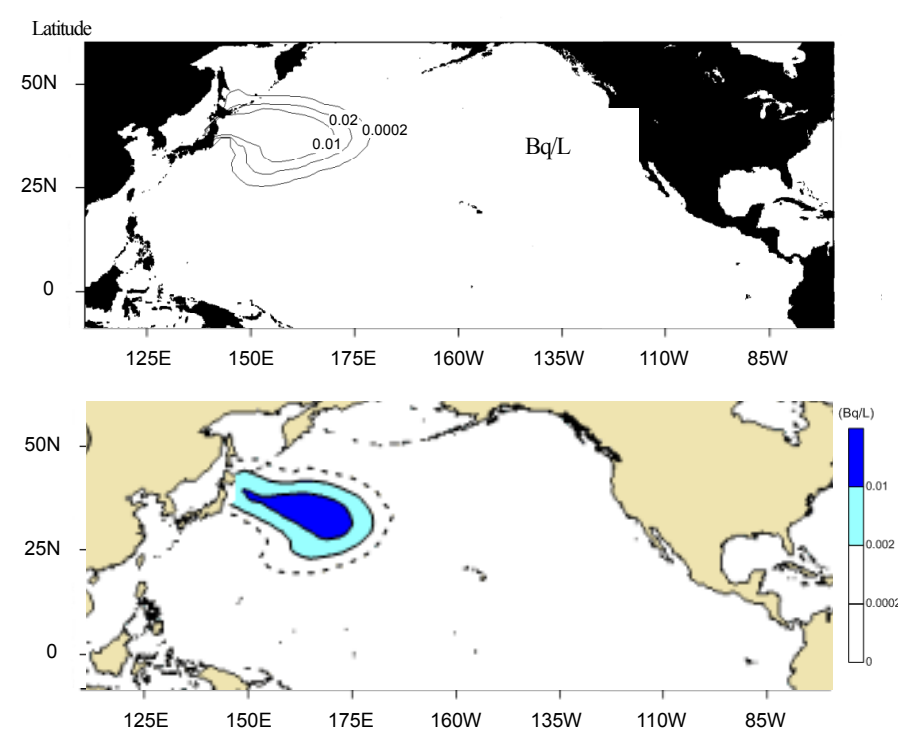

図-2 太平洋における ${ }^{137} \operatorname{Cs}$ の拡散状況（1 年後 : 表層） （上図 : 計算結果，下図 : LAMERIによる結果）

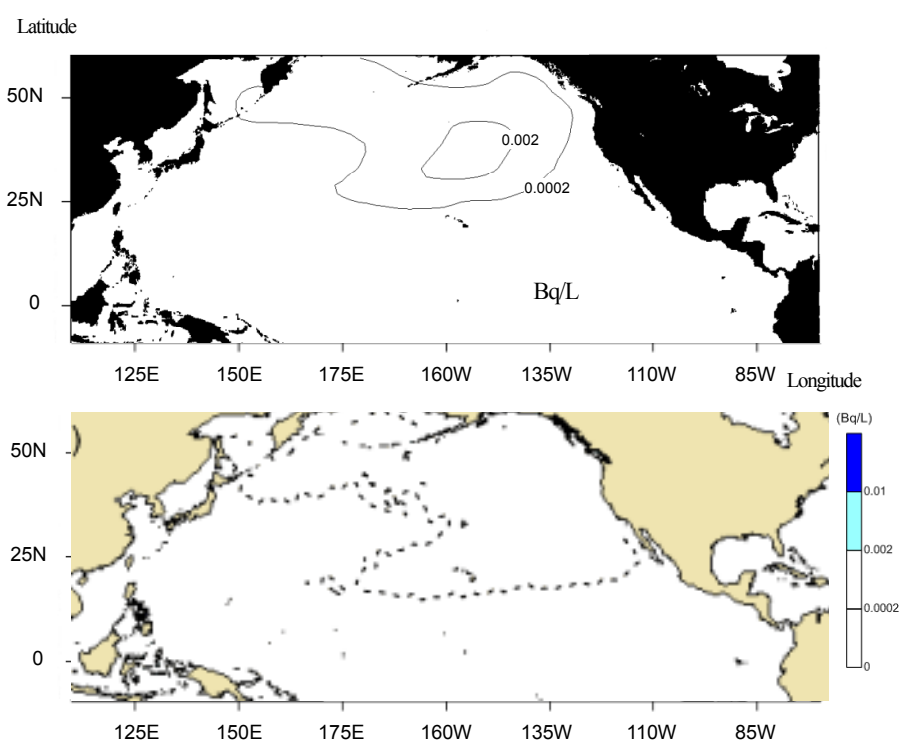

図-3 太平洋における ${ }^{137} \operatorname{Cs}$ の拡散状況（7 年後 : 表層) (上図 : 計算結果, 下図 : LAMER ${ }^{10)} に よ る$ 結果)

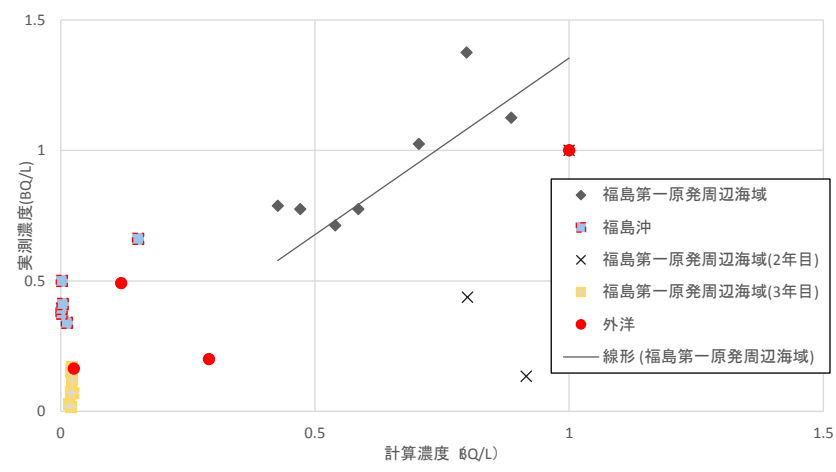

図-4 実測値 ${ }^{12), 13), 14) 15) 16)}$ と計算值の相関関係 ( 1 年後 : 表層)

からのフォールアウトが大きな負荷源である. 本研究で は, 総負荷量として大気への放射性物質の放出量を包含 しているものの, 福島沖に風による移送後に海洋へ フォールアウトした面的作用は考慮していない，また， 


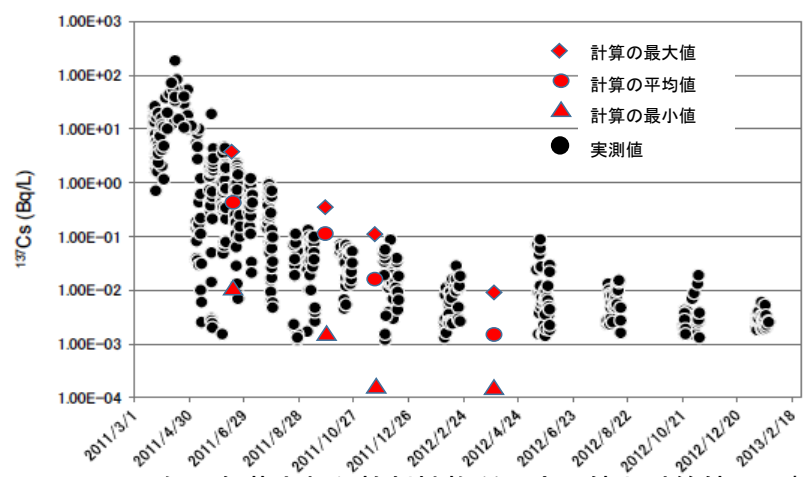

図-5 2011年に負荷された放射性物質の実測值亡計算值の比較

福島第一原発周辺における数年後の実測值と計算值の比 較においても相関関係は低い.この原因として，本研究 では2011年に発生した事故により負荷された放射性物質 を負荷量としたが，2011年から数年後に至る過程におい て持続した放射性物質の漏洩が指摘されている ${ }^{17), 18)}$. そ こで，事故直後にのみ負荷された放射性物質に対する本 モデルの精度検証のため, 宮城・福島・茨城県沖の高濃 度時 (事故から短期間) における計算值と実測值 ${ }^{12}$ との 比較を行った。これによれば，各時期における計算結果 と実測值はほぼ同じ範囲内にあり，また両者ともに類似 した濃度の減少傾向を示している。これらのことから概 ね妥当な計算結果が得られていると考えられ，このモデ ルを用いて放射性污染水の検討を行うこととした.

\section{4．污染水における放射性物質濃度解析}

\section{(1) 計算条件}

山や河川などを介して東京電力(株)福島第一原発敷地内 に流入した地下水は，高濃度放射性物質によって污染水 と化している．福島第一原子力発電所は海に面している ことから，こうした污染水は何れ海域一と漏洩すると考 えられる. 污染水は放射性核種除去装置（アルプス）に

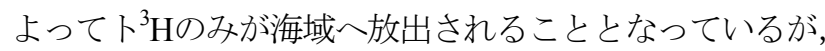
ここではアルプスが停止した事態や凍土による污染水対 策などを踏まえて 1 日に増加する污染水が，そのまま海
表-2 拡散計算の諸条件

\begin{tabular}{|l|l|l|}
\hline \multicolumn{2}{|c|}{ 項目 } & 設定值 \\
\hline \multirow{4}{*}{ 負荷量 } & ${ }^{137} \mathrm{Cs}$ & $\begin{array}{l}9.3 \times 10^{7} \mathrm{~Bq} / \mathrm{m}^{3} \times 400 \mathrm{~m}^{3} / \mathrm{day}^{12)} \\
=2.58 \times 10^{8} \mathrm{~Bq} / \mathrm{dt}\end{array}$ \\
\cline { 2 - 3 } & ${ }^{90} \mathrm{Sr}$ & $\begin{array}{l}5.0 \times 10^{9} \mathrm{~Bq} / \mathrm{m}^{3} \times 400 \mathrm{~m}^{3} / \mathrm{day}^{12)} \\
=1.39 \times 10^{10} \mathrm{~Bq} / \mathrm{dt}\end{array}$ \\
\cline { 2 - 3 } & ${ }^{3} \mathrm{H}$ & $\begin{array}{l}6.3 \times 10^{5} \mathrm{~Bq} / \mathrm{m}^{3} \times 400 \mathrm{~m}^{3} / \mathrm{day}{ }^{12)} \\
=1.75 \times 10^{9} \mathrm{~Bq} / \mathrm{dt}\end{array}$ \\
\hline \multirow{2}{*}{$\begin{array}{l}\text { 放射性物質の } \\
\text { 半減期 }\end{array}$} & ${ }^{137} \mathrm{Cs}$ & 30 年 \\
\cline { 2 - 3 } & ${ }^{90} \mathrm{Sr}$ & 28.8 年 \\
\cline { 2 - 3 } & ${ }^{3} \mathrm{H}$ & 12 年 \\
\hline 放射性物質の & ${ }^{137} \mathrm{Cs}$ & $2.0 \times 10^{-3} \mathrm{~m}^{3} / \mathrm{g}$ \\
\cline { 2 - 3 } 分配係数(Kd) & ${ }^{90} \mathrm{Sr}$ & $2.0 \times 10^{-4} \mathrm{~m}^{3} / \mathrm{g}$ \\
\cline { 2 - 3 }${ }^{3} \mathrm{H}$ & $0.0 \times 10^{-3} \mathrm{~m}^{3} / \mathrm{g}$ \\
\hline 海表面からのフォールアウト & 考慮しない \\
\hline 初期值 & $0 \mathrm{~Bq} / \mathrm{L}$ \\
\hline 計算時間 & 5 年間 \\
\hline
\end{tabular}

域へ放出されることを想定する。したがって，放射性物 質は ${ }^{137} \mathrm{Cs} の$ 他に ${ }^{90} \mathrm{Sr},{ }^{3} \mathrm{H}$ の放出を想定した. 負荷量は, 污染水 ${ }^{\text {量 }}{ }^{19)}$ に福島第一原子力発電所内で東京電力(株に よって実測されている高濃度放射性物質 ${ }^{20)}$ の最大濃度を 掛け合わせることで算出した，なお，濃度測定は定期的 に行われているが, 本研究では安全側及び環境影響評価 の考え方から，過去の最大濃度を用いた．放出地点は福 島第一原子力発電所前面海域の 1 メッュとし, 放出時 間及び計算時間は 5 年とした。 表-2に計算条件を示す.

\section{（2）計算結果}

まず，図-5に計算開始から1週間後における福島第一 原子力発電所前面 $\left(\mathrm{N} 36.6^{\circ} \sim \mathrm{N} 38.2^{\circ}, \mathrm{E} 140.6^{\circ} \sim\right.$ E142.6 $\left.6^{\circ}\right) の^{137} \mathrm{Cs},{ }^{90} \mathrm{Sr},{ }^{3} \mathrm{H}$ の濃度計算結果を示寸. 3核 種ともに, 福島第一原子力発電所近傍での濃度上昇が見 られるものの，範囲は限定的になっている. 137Csの最 大濃度上昇は $4.3 \mathrm{mBq} / \mathrm{L},{ }^{90} \mathrm{Sr}$ の最大濃度上昇は $231.43 \mathrm{mBq} / \mathrm{L},{ }^{3} \mathrm{H}$ の最大濃度上昇は $29.1 \mathrm{mBq} / \mathrm{L} て ゙ 3$ 核種と もに福島第一原子力発電所前面が最大濃度上昇地点で あった. ${ }^{90} \mathrm{Sr}$ の最大濃度上昇は比較的高く, 想定した負 荷量の場合早い段階（1週間）で高濃度となることが分 かった.
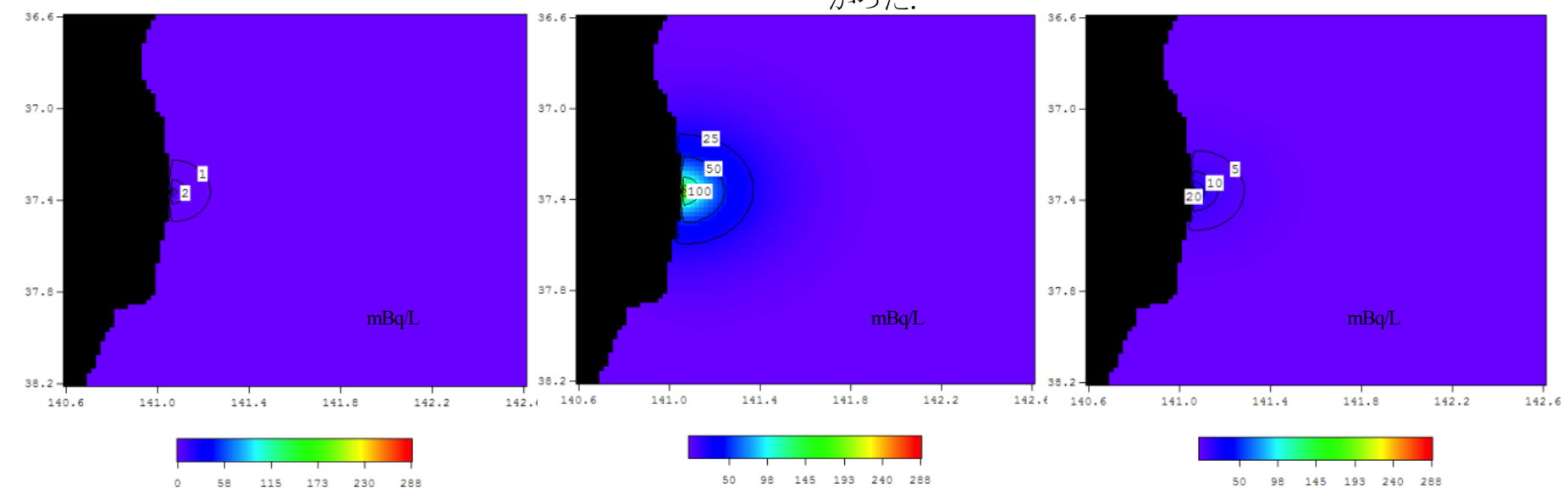

図-6 放射性物質濃度計算結果 (1週間後 : 表層)

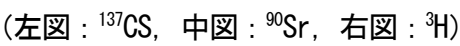



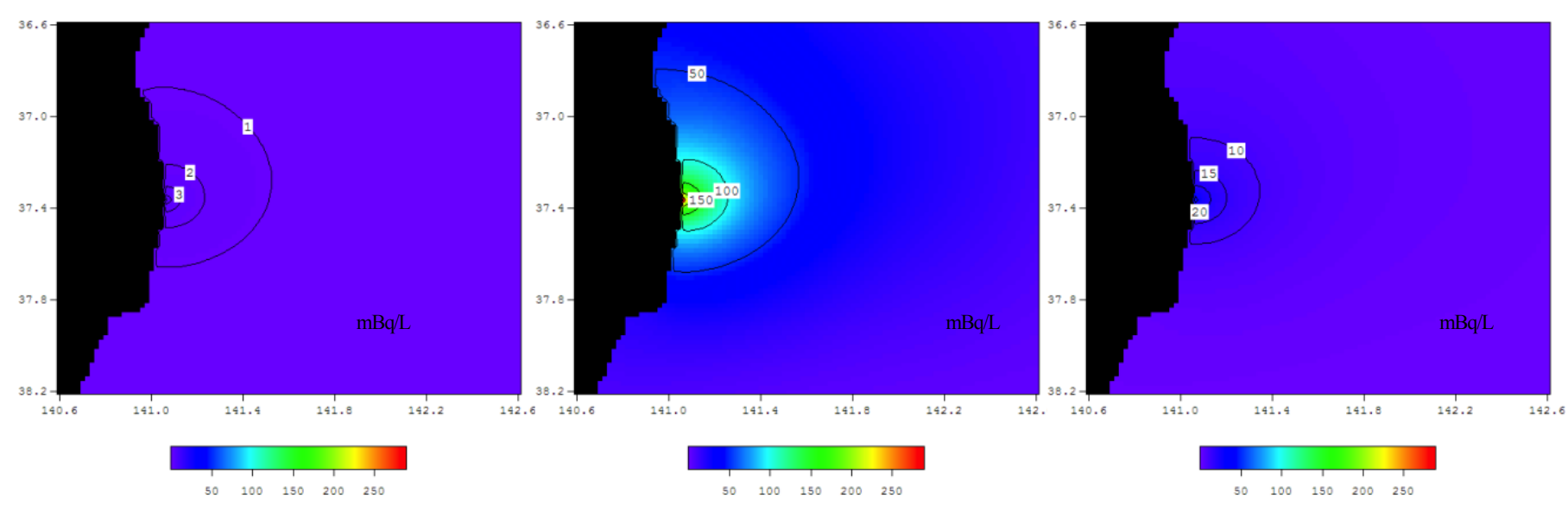

図-7 放射性物質濃度計算結果 (5年後 : 表層)

（左図: ${ }^{137} \mathrm{CS}$, 中図 : ${ }^{90} \mathrm{Sr}$, 右図 : ${ }^{3} \mathrm{H}$ )

また，放射性核種が放射状に拡散することから，表層 での流れの影響は強くないと考えられる.

図-6に5年後における ${ }^{137} \mathrm{Cs},{ }^{90} \mathrm{Sr},{ }^{3} \mathrm{H}$ の濃度計算結果を 示寸. 3核種ともに, 福島第一原子力発電所近傍での濃 度上昇が見られるものの，範囲は限定的 $(50 \mathrm{~km} \times 50 \mathrm{~km})$ になっている. ${ }^{137} \mathrm{Cs} の$ 最大濃度上昇は $5.35 \mathrm{mBq} / \mathrm{L},{ }^{90} \mathrm{Sr} の$ 最大濃度上昇は $288.45 \mathrm{mBq} / \mathrm{L},{ }^{3} \mathrm{H}$ の最大濃度上昇は $4.4 \times$ $10^{4} \mathrm{mBq} / \mathrm{L}$ で3核種ともに福島第一原子力発電所前面が最 大濃度上昇地点であった. 3 核種の比較では ${ }^{90} \mathrm{Sr}$ の濃度上 昇が最も高く, 次いで $\mathrm{H}^{3},{ }^{137} \mathrm{Cs}$ の順であるが大きな差は なかった，一方で，核種ごとに負荷量が異なることから 濃度低減の直接的比較が難しいため，次に示寸定義に基 づいて低減率（低減率=計算期間中の最大濃度上昇/ $\Delta \mathrm{t} の$ 負荷量に対する最大濃度上昇地点での濃度）の比較を 行った。この結果 ${ }^{137} \mathrm{Cs}$ の低減率は3.2 $\times 10^{-5},{ }^{90} \mathrm{Sr} は 3.2 \times$ $10^{-5},{ }^{3} \mathrm{H}$ は2.0 $\times 10^{-5}$ となり, 各種ごとに顕著な差は見ら れなかった。 なお， 1年後における3核種の濃度計算結果 は，5年後の計算結果と比較し大きな変化は見られな かったため，ここでは図面を省略した．このことから， 污染水の拡散は1年後までにほぼ収束していることが分 かった。

次に, 想定した人口的に放出する放射性污染水がどの 程度の濃度上昇であるのかを把握するため, 昭和 58 年か ら平成24年にわたる福島第一原発前面海域における実測 值 ${ }^{14)}$ との比較を行った（図-8参照）。青の破線が ${ }^{137} \mathrm{Cs}$, 緑 の破線が ${ }^{90} \mathrm{Sr}$ で5年後の計算結果の最大值を示している. なお，実測值がないことから ${ }^{3} \mathrm{H} の$ 比較は行っていない. この結果，比較的高濃度の污染水の放出を想定した場合 でも，污染水による影響は， ${ }^{137} \mathrm{Cs}$ では過去の海水中に観 測されたレベルに留まること, ${ }^{90} \mathrm{Sr}$ では東日本大震災当 時(2011年)のレベルまで上昇することが分かった。なお， 実測值では ${ }^{137} \mathrm{Cs} の$ 值が ${ }^{90} \mathrm{Sr}$ と比べ高いが, 計算值では ${ }^{90} \mathrm{Sr}$ が高くなっている。これは，実海域での ${ }^{90} \mathrm{Sr}$ の存在量及 び海域への放出量が小さいのに対し, 計算では福島第一 原発内で計測された放射性物質濃度の最大值を污染水と 設定したことによるものと考えられる.

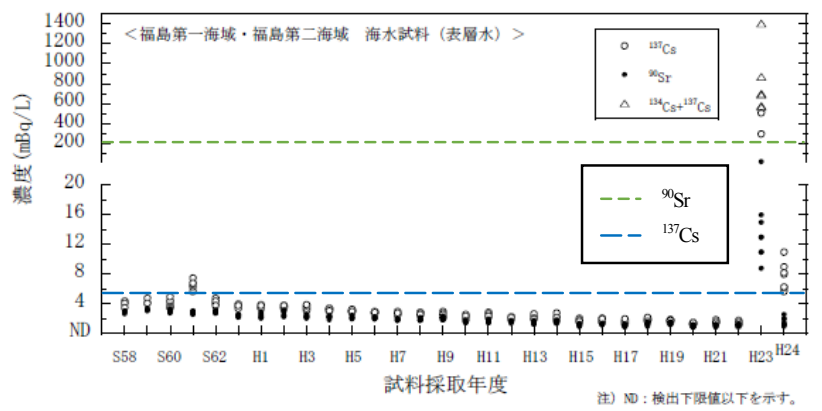

図-8 実測値 ${ }^{14)}$ と計算結果 (5年後)の比較

\section{5．放射性物質による影響評価}

放射性物質の負荷によって, 懸念されることは魚類 などに濃縮した放射性物質を間接的に体内に取り込む ことである．特に人工的に放射性物質の放出を行うに は，海産生物を介しての影響が考えられる人体への影 響を把握，管理する必要がある，そこで，国際放射線 防護委員会(ICRP)による計算手法を用いて，今回の污 染水の放出が人体に影響を与えるかについて検討を以 下の式によって行った。内部被爆により，人体が影響 を受ける程度を示す放射線量は預託実効線量と呼ばれ， 海洋生産物の1年間摂取による線量によって評価される.

$$
D_{i}=365 H_{i k} W_{j} C F_{k j} C_{k}
$$

ここで, $D_{i}$ : 海洋生産物 (i) を 1 年間摂取したことによ る線量 $(\mathrm{Sv} / \mathrm{y}), H_{i k}: \mathrm{Cs}(\mathrm{k}) 1 \mathrm{~Bq}$ を経口摂取したときの預 託実効線量当量 $(\mathrm{Sv} / \mathrm{Bq}), W_{j}$ : 海洋生産物を 1 年間摂取 する量 (g/day)， $C F_{k j}:{ }^{137} \mathrm{Cs}$ に対する魚の濃縮係数 $\left(\mathrm{g} / \mathrm{cm}^{3}\right), C_{k}$ : 海水濃度 $\left(\mathrm{Bq} / \mathrm{cm}^{3}\right)$ である. 海洋生産物の 摂取量は, 厚生労働省による国民健康・栄養調査

（2003～2010年）のうち, 魚介類, 魚介加工品, 藻類 の平均摂取量 $120.9 \mathrm{~g}$ /日とした. また, 預託実効線量当 量はICRPから $\left.1.3 \times 10^{-8} \mathrm{~Sv} / \mathrm{Bq}\left({ }^{137} \mathrm{Cs}\right), \quad 2.8 \times 10^{-8} \mathrm{~Sv} / \mathrm{Bq}{ }^{90} \mathrm{Sr}\right)$ とした，魚の濃縮係数は渡部 ${ }^{21)}$ を参考に，魚介類およ 
び魚介加工品は $100 \mathrm{~g} / \mathrm{cm}^{3}$, 藻類は $50 \mathrm{~g} / \mathrm{cm}^{3}$ とした.

今回の放射性物質の計算結果によれば，1年後及び5 年後の放射性 ${ }^{137} \mathrm{Cs}$ は海水の最大濃度で $5.35 \times 10^{-3} \mathrm{~Bq} / \mathrm{L}$, ${ }^{90} \mathrm{Sr}$ は海水の最大濃度で $288.45 \times 10^{-3} \mathrm{~Bq} / \mathrm{L}$ である.この 值から算出された線量は $4.3 \times 10^{-4} \mathrm{mSv} / \mathrm{y}, 2.3 \times 10^{-2} \mathrm{mSv} / \mathrm{y}$ である。これは，污染水の影響を受けた魚介系のみを 摂取した場合でもICRPが定めた限界值 $(1 \mathrm{mSv} / \mathrm{y})$ より相 当小さい值となることを示している.

\section{6. まとめ}

本研究では, 東日本大震災の影響に伴う福島第一原子 力発電所の放射性污染水がもたらす海洋への中期的な影 響について検討するため, 太平洋循環モデルからネス ティング手法によってメッシュを細分化し，放射性物質 の崩壊・スキャベンジングを考慮したモデルの展開を 行った. モデルの検証として，2011年に海域へ放出され た放射性物質を対象とし，既往の知見及び実測值と本研 究における放射性物質の濃度計算結果との比較を行いモ デルが妥当であることを確認した.

このモデルを用いて実施した放射性污染水の計算結果 及び影響評価については，以下に示寸とおりである。

(1) 污染水の拡散は連続的に放出しても, 1 年以内に収 束すると想定される.

(2) ${ }^{137} \mathrm{Cs},{ }^{90} \mathrm{Sr},{ }^{3} \mathrm{H}$ の污染水濃度は, 福島第一原子力発 電所前面海域周辺に限定され各種による希勫の差は ほとんどなかった。

(3) ${ }^{90} \mathrm{Sr}$ の最大濃度は，2011年頃と同レベルとなる.

(4) ${ }^{137} \mathrm{Cs},{ }^{90} \mathrm{Sr}$ の人体への影響は污染水の影響を受けた 魚介系のみを摂取した場合でもほぼないと考えら れる。

本研究では，放射性物質特有の拡散現象（スキャベン ジング, 崩壊）は顕著には見られなかった。これは,

${ }^{137} \mathrm{Cs},{ }^{90} \mathrm{Sr},{ }^{3} \mathrm{H}$ の分配係数が比較的小さく, 計算期間が 半減期より短いためと考えられる.

また，実測との比較において2011年事故当時の負荷量 のみを想定した予測では長期における実測との比較に差 異が生じる．したがって，長期的な予測を行うには把握 可能な負荷源, 負荷量を全て考慮することが望まれる.

今回の想定はアルプスの停止など，危険を想定したも のではあるが，ある特定の行為（人口的な污染水の排 出）に対する環境影響評価としての知見には十分である と考えられる. 今後は，他の核種での想定や総負荷量の 推定，恒常的な海域一の放出として河川からの負荷に対 寸る拡散解析の検討が必要であると考えられる.

\section{参考文献}

1)津旨ほか : 福島第一原子力発電所から漏洩した $137 \mathrm{Cs}$ の海洋 拡散シミュレーション, 電力中央研究所報告書V11002.,
2011.

2)松浦ほか : 福島第一原子力発電所から海一漏洩したセシウム 137の拡散計算, 土木学会論文集B1, No.4, p.I_1399-I_1404, 2013.

3)Honda et al:: Dispersion of artificial caesium-134 and -137 in the western North Pacific one month after the Fukushima accident. Accepted by Geochemical Journal.

4)Godlberg,E.D.: Marine geochemistry, J.Geol.62, 249-265, 1954.

5)Wada, Nagoya: Pacific Ocean flow simulation using the data assimilation system, Flow Modeling and Turbulence Measurements VI, pp.631-637, 1996.

6)Hasegawa et al.: Calculations of the concentration of radionuclides (137Cs, 90Sr,Pu-239/240) in The Pacific Ocean, Journal of Hydroscience and Hydraulic Engineering,20, 2, p.277-237, November, 2002.

7)中村ほか : 数值モデルを用いた日本近海における $\mathrm{CO}_{2}$ 海洋隔 離による $\mathrm{CO}_{2}$ 濃度影響評価, 海洋調査技術学会誌, Vol.42, 2009.

8)水落, 和田 : 北極海における放射能濃度解析, 土木学会第58 回年次学術講演会, 2003.

9)津旨ほか : 海洋大循環モデルを用いた海洋中核種濃度評価手 法の開発，電中研報告U99007，1999.

10)津旨, 丸山 : 日本海における海洋中核種濃度計算法, 電中 研報告U00040， 2001.

11)独立行政法人日本原子力研究開発機構 : 太平洋における放 射能濃度分布のシミュレーションについて，2011。

12)東京電力株式会社 : 東京電力株式会社福島第一原子力発電 所周辺の海水の放射能分布, Apr., 2014

13)原子力規制庁 : 東京電力株式会社福島第一原子力発電所周 辺の海域モニタリング結果（海水）, Jun., 2014

14)原子力規制庁 : 平成24年度に実施された海洋環境放射能総 合評価事業の概要, 2014.

15)海上保安庁 : 放射能調查報告書 平成24年調査結果, Mar., 2014.

16)文部科学省：外洋における海洋モニタリング (海水) の結 果, Nov. 2012.

17)Kanda: Continuing ${ }^{137} \mathrm{Cs}$ release to the sea from the Fukushima Daiichi Nuclear Power Plant through, Biogeosciences, Vol.10, p.61076113, 2012.

18)Tsumune et al.: One-year, regional-scale simulation of ${ }^{137} \mathrm{Cs}$ radioactivity in theocean following the Fukushima Dai-ichi Nuclear Power Plant accident, Biogeosciences, Vol.10, p.5601-5617, 2012.

19)東京電力株式会社 : 福島第一港湾内、放水口付近、護岸の 詳細分析結果, May., 2014.

20)東京電力株式会社 : 福島第一原子力発電所における污染水 対策について, Sep., 2013.

21)渡部: 海洋生物への放射性物質の移行, 環境パラメータ・ シリーズ6, 原子力環境整備センター, 1996.

(2014. 9. 30受付) 